\title{
Study of the Specificity of Cross-Povidone (PVPP) as Binding Agent in the Quantification of Polyphenolic Compounds
}

\author{
Simone G. Verza, ${ }^{a}$ Cabral Pavei and George G. Ortega ${ }^{*, a}$ \\ ${ }^{a}$ Programa de Pós-Graduação em Ciências Farmacêuticas, Faculdade de Farmácia, Universidade Federal do \\ Rio Grande do Sul, Av. Ipiranga 2752, 90610-000 Porto Alegre-RS, Brazil
}

\begin{abstract}
O polímero polivinilpirrolidona (PVPP) proporciona uma alternativa analítica ao invés do pó-de-pele e caseína, como um agente complexante na quantificação de taninos. Neste trabalho foi estudado a especificidade do PVPP em complexar com compostos polifenólicos, na presença de rutina. Os ácidos gálico e tânico, catequina e pirogalol foram utilizados como substâncias de referência (PRS), junto com o extrato aquoso das folhas do Psidium guajava L. A especificidade da complexação foi avaliada pelo método espectrofotométrico e por cromatografia líquida de alta eficiência (CLAE) com arranjo de diodos (DAD). As análises para a mistura das PRS e rutina, demonstraram claramente que a complexação com PVPP não é uma reação específica e independe da quantidade de polímero utilizada. As análises por CLAE-DAD do extrato de Psidium guajava revelaram picos característicos de flavonóides, além de catequina e ácido gálico. Todos os picos destes flavonóides, catequina e ácido gálico decresceram quando adicionou-se o PVPP. Isto confirma a falta de especificidade. Desde que a ligação PVPP-polifenóis depende de características estruturais particulares, a extensão desses resultados a outras espécies vegetais deve ser evitada.
\end{abstract}

Cross-povidone, or polyvinylpyrrolidone (PVPP) affords an analytical alternative instead of hide-powder and casein as binding agent in the content assay of vegetable tannins. In this work we studied the specificity of PVPP to bind polyphenolics in the presence of flavonoids. Gallic acid, tannic acid, catechin and pyrogallol were used as polyphenolic reference substances (PRS), along with an aqueous extract from Psidium guajava L. leaves. The binding specificity was assayed by UV-Vis and High Performance Liquid Chromatography-Photodiode array (HPLC-PDA) methods. The analyses of PRS-rutin mixtures showed clearly that PVPP binding is a non-specific reaction, unrelated to the amount of PVPP used. HPLC-PDA analysis revealed peaks which could be characterized as flavonoids in the Psidium guajava extract, beside catechin and gallic acid. All these flavonoids, catechin and gallic acid peaks decreased as PVPP was added; this confirms the lack of specificity. Since the polyphenolic-PVPP reaction depends on specific structural features, any extensive conclusion should be avoided.

Keywords: PVPP, tannins, flavonoids, specificity, HPLC-PDA

\section{Introduction}

Almost all of the assays of polyphenolics and tannin content in current chemical Codexes and Pharmacopoeias are based on polyphenol-protein binding. For that purpose hide-powder and casein are normally used as protein substrates..$^{1-5}$ On a following step the assays are accomplished with a spectrophotometric quantitation by the Folin-Ciocalteu method. ${ }^{6,7}$ It was recently demonstrated that methods using hide-powder and casein are non-specific when flavonoids are also present in the reaction milieu. ${ }^{5,8}$

*e-mail: ortega@farmacia.ufrgs.br
The lack of specificity was also related to other methods intended for the tannin assay, including gravimetric and HPLC-UV methods. ${ }^{9,10}$

The capacity of insoluble cross-linked povidone (PVPP) to bind polyphenols arises in this context as a seldom explored analytical alternative. ${ }^{5,11,12}$ One example of this is the FAO/ IAEA method for the Quantification of Tannins in Tree Foliage Monograph. ${ }^{7}$ The capacity of PVPP to bind polyphenolics was earlier ascribed to the structural likeness between the pyrrolidone group and the amino acid proline. ${ }^{13}$ Other main factors determining the polyphenolics-PVPP reaction include chemical features of the polyphenol molecule (number of hydroxyl groups, isomers and conformation features) 
as well as the $\mathrm{pH}$, temperature and ionic strength of the reaction milieu..$^{5,11,12,14-16}$ This work was designed to evaluate systematically analytical variables related to the binding reaction between PVPP and the reference substances, gallic acid, tannic acid, catechin and pyrogallol. Complementary, an aqueous extract from Psidium guajava leaves was included as a model plant extract. Psidium guajava is a plant that provides a large amount of polyphenols, among them gallic acid and catechin. Flavonoids are reported for P. guajava such as quercetin and its glycosilates derivatives. ${ }^{17-21}$

\section{Experimental}

\section{Chemicals}

Standard substances gallic acid, catechin, tannic acid and rutin were purchased from Sigma (St. Louis, MO). Pyrogallol, anhydrous sodium carbonate, and HPLC solvents were purchased from Merck (Darmstadt, Germany). PVPP was purchased from Sigma and purified by acidic washing before its use.

\section{Plant material}

P. guajava L. leaves were harvested in Porto Alegre County (march, 2004), dried in an air-circulating oven (Memmert, TV $60 \mathrm{UL}$, Germany) at $40{ }^{\circ} \mathrm{C}$ for five days. The dried material was comminuted in a cutter mill (SK1 Retsch, Germany). The powder fraction with a particle size of $180 \mu \mathrm{m}$ was stored in glass vessels, protected from light. The water content was determined using the Loss-on-drying Assay of the German Pharmacopoeia. ${ }^{2}$

\section{Extract preparation}

A mass of $0.5 \mathrm{~g}$ of plant material was extracted with $150.0 \mathrm{~mL}$ of water by heating at $100{ }^{\circ} \mathrm{C}$ on a water-bath for $30 \mathrm{~min}$. The extract was cooled at room temperature, transferred quantitatively to a $250 \mathrm{~mL}$ volumetric flask and diluted up to $250.0 \mathrm{~mL}$ with water. The solution was filtered through a Whatmann paper filter discarding the first $50 \mathrm{~mL}$ of filtrate. The remaining filtrate was freeze-dried and stored adequately until it was used.

\section{Preparation of standard solutions}

Standard solutions were freshly prepared daily with purified water so that final concentrations of $0.4 \mathrm{mg} \mathrm{mL}^{-1}$ (tannic acid and gallic acid), $1.4 \mathrm{mg} \mathrm{mL}^{-1}$ (catechin) and $3.0 \mathrm{mg} \mathrm{mL}^{-1}$ (pyrogallol) were obtained and used immediately. All preparations were protected from light full-time.

\section{Preparation of PVPP dispersions}

Four samples of PVPP were accurately weighted and magnetically stirred with purified water during $24 \mathrm{~h}$ so that final concentrations of 0.5. 2.5. 7.5 and $15 \mathrm{mg} \mathrm{mL}^{-1}$ were obtained. After this hydration procedure, the preparations were used at once.

\section{Comparison of PVPP-PRS complexes}

A $5.0 \mathrm{~mL}$ aliquot of each polyphenolic reference substances (PRS) solution was added to each one of four PVPP dispersions. The mixture was stirred magnetically during $30 \mathrm{~min}$. The mixture was centrifuged at $3000 \mathrm{rpm}$ (2.01 $\mathrm{g}$ ) for $30 \mathrm{~min}$ (Fanem, Brazil), and the supernatant liquid then decanted and retained. A $5.0 \mathrm{~mL}$ aliquot of each preparation was diluted up to $25.0 \mathrm{~mL}$ with water. The absorption was measured at 270 (for gallic acid and tannic acid), 280 (for catechin), and $267 \mathrm{~nm}$ (for pyrogallol) using water as a blank and a double beam spectrophotometer (Hewlett Packard, HP8452A, USA). Three replicate procedures were carried out with each PRS solution.

\section{Influence of the $\mathrm{pH}$ on the catechin fraction bound}

Eight $700 \mu \mathrm{g} \mathrm{mL}^{-1}$ solutions of catechin were mixed separately with $20 \mathrm{~mL}$ of a $15 \mathrm{mg} \mathrm{mL}^{-1}$ PVPP dispersion (prepared as described above for PVPP dispersions). The $\mathrm{pH}$ was adjusted at 2.94 and 3.36 using $\mathrm{HCl} 0.1 \mathrm{~mol} \mathrm{~L}^{-1}$; at 6.99 and 7.98 with phosphate buffer, and at $8.43,8.99$, and 9.39 with borate buffer. ${ }^{5}$ The mixture at $\mathrm{pH} 6.0$ contained water alone. After that, each preparation was treated as described in Comparison of PVPP-PRS complexes, above item. The absorption was measured at $280 \mathrm{~nm}$ (acidic $\mathrm{pH}$ ) or $290 \mathrm{~nm}$ (alkaline $\mathrm{pH}$ ), using purified water as a blank. The results were expressed as catechin bound fraction $(\mathrm{CBF})$ and represent the mean value of at least three replications.

\section{HPLC-assay for the PVPP binding specificity}

Solutions containing $80 \mu \mathrm{g} \mathrm{mL} \mathrm{m}^{-1}$ of gallic acid, catechin, pyrogallol and rutin were prepared separately using an acetonitrile:water $(1: 3 \mathrm{v} / \mathrm{v})$ mixture as a solvent. From each solution, $10.0 \mathrm{~mL}$ aliquots were mixed with 10.0, 50.0, 150.0, and $300.0 \mathrm{mg}$ of PVPP and afterward stirred, centrifuged and decanted as described for Comparison of PVPP-PRS complexes, above item. Appropriate aliquots from the decanted liquid were filtered through a $0.45 \mu \mathrm{m}$ polyvinylidene difluoride (PVDF) filter. The injection volume was $20 \mu \mathrm{L}$. 
For the P. guajava extract analysis, a $100.0 \mathrm{mg}$ sample of freeze-dried extract was dissolved in water, filtered through a $0.45 \mu \mathrm{m}$ PVDF syringe filter and injected. Aliquots of $10.0 \mathrm{~mL}$ of this solution were treated with $10.0 ; 50.0 ; 150.0$ and $300.0 \mathrm{mg}$ of PVPP, stirred by $30 \mathrm{~min}$ magnetically, filtered in the same way and injected. Each result represents the mean value of at least three replicate.

The samples were analyzed with a Waters Alliance HPLC system (Mod. 2695, USA) equipped with a model 2695 solvent delivery system, a model 2487 programmable UV/Vis detector (Waters, 2487) and a photodiode-array (PDA) detector (Waters, 996); the system was controlled by Waters Empower software. The samples were loaded onto a reversed phase $\mathrm{C}_{18}$ Gemini column (Phenomenex, $250 \mathrm{~mm} \times 4.60 \mathrm{~mm}, 5 \mu \mathrm{m}$ particle size) preceded by a $\mathrm{C}_{18}$ guard cartridge (Shimadzu, $10 \mathrm{~mm} \times 4 \mathrm{~mm}$ ), packed with Bondapack $\mathrm{C}_{18} 125 \mathrm{~A}, 37-55 \mu \mathrm{m}$. The temperature was kept at $20-25{ }^{\circ} \mathrm{C}$. For quantification purposes dual wavelength detection of the standards was performed at 280 and $352 \mathrm{~nm}$. HPLC analysis at $352 \mathrm{~nm}$ was used for detection and characterization of rutin and P. guajava flavonoids. The detection sensitivity was set to 0.5 U.A. The mobile phases consisted of two mixtures: aqueous $0.5 \%$ phosphoric acid (A) and acetonitrile $+0.5 \%$ phosphoric acid $(60: 40 \mathrm{~m} / \mathrm{m})(B)$. The mobile phase gradient in weight ratio was as follows: 13 to $25 \% \mathrm{~B}$ over $25 \mathrm{~min}$ (step 1); $25 \% \mathrm{~B}$, isocratic over $5 \mathrm{~min}$ (Step 2); 25 to $33 \%$ B over $7 \mathrm{~min}$ (step 3); $33 \% \mathrm{~B}$, isocratic over $3 \mathrm{~min}$ (step 4); 33 to $40 \%$ B over 7 min (step 5); $40 \% \mathrm{~B}$, isocratic over 3 min (step 6); 40 to $43 \%$ B over 3 min (step 7); $43 \%$ B, isocratic over 2 min (step 8); 43 to $13 \% \mathrm{~B}$, over 15 min (column clean up). The flow rate was $0.8 \mathrm{~mL} \mathrm{~min}^{-1}$.

\section{$U V$-assay for the PVPP binding specificity}

The quantitation of PRS was carried out spectrophotometrically in a similar way as described for Comparison of PVPP-PRS complexes, above item. In this case, $100.0 \mathrm{~mL}$ samples of catechin and pyrogallol standard solutions were spiked with $20.0 \mathrm{mg}$ of rutin separately. Both spiked solutions were treated as described above for Comparison of PVPP-PRS complexes, above item. The analysis was performed at 280 (catechin), 267 (pyrogallol), and $352 \mathrm{~nm}$ (rutin).

\section{Results and Discussion}

In the current work, one of the objectives was the comparison of the binding of PVPP to four standard substances frequently used to express tannin or polyphenols content, namely gallic acid, tannic acid, catechin and pyrogallol. Together with the standard substances, an extract from $P$. guajava leaves was included as a model plant extract, owing it tannin, flavonoids and other polyphenolics richness. ${ }^{17-21}$ Rutin was chosen as the model glycosidic flavonoid because of its ubiquitous distribution in higher plant species. The analyses of polyphenolic reference substances (PRS), rutin and P. guajava extract were performed by spectrophotometry and HPLC-PDA. The HPLC-PDA method was particularly developed for the detection and quantification of the PRS P. guajava extract and the flavonoid rutin.

The simple comparison of the free polyphenolic fraction curves exposed clear binding differences in terms of polyphenolic-PVPP complex formation (Figure 1).



Figure 1. Complexation of gallic acid $(\square)$, tannic acid $(\mathbf{\Delta})$, catechin $(O)$, pyrogallol $(\bullet$ ) and $P$. guajava extract $(\triangle)$ with PVPP by UV detection in characteristic wavelength of each PRS.

The foremost drive mechanism linked to the PVPP binding is associated to its extremely hydrophilic structure, which implies intermolecular hydrogen binding. ${ }^{22}$ Earlier studies showed that affinity to PVPP was generally increased with the number of phenolic hydroxy groups available for hydrogen bonding. ${ }^{14}$ This should explain the strong interaction between PVPP and tannic acid, which contains many hydroxyl groups in its numerous galloyl groups. ${ }^{11,23}$ Similar results were related earlier for tannic acid and catechin studies using gelatin and trypsin as protein substrates..$^{24,25}$ These authors ascribed the better complexation of tannic acid to its higher molecular weight and hydroxyl density.

The PVPP-gallic acid interaction was higher than that observed for pyrogallol, owing probably the more reactive carboxylic group attached to gallic acid molecule. Previous studies with PVPP and several drugs revealed that the carboxylic groups were more effective than the hydroxylic groups in complexation with the PVPP. ${ }^{11}$

In the PVPP-catechin case, the complexation involves the five hydroxyls attached to C3, C5, C7, C3' and C4' sites, plus the hydrophobic bonding contribution. When the catechin bound fraction $(\mathrm{CBF})$ curve is compared to the gallic acid ones, it becomes evident that the five catechin hydroxyl 
surpasses the total effect due to the three hydroxyl groups and one carboxylic acid attached to the gallic acid molecule.

Besides being an important tannin fraction, P. guajava leaves contain flavonoids and other polyphenolics. ${ }^{16,18,19,21,26,27}$ The binding behavior of the P. guajava extract was comparable to tannic acid and catechin, as observed in Figure 1.

The influence of the $\mathrm{pH}$ on the binding effectiveness of PVPP is well-documented in the literature. ${ }^{5,14,15,27}$ Catechin was chosen to evaluate the $\mathrm{pH}$ influence on the binding capacity because its interaction was greater than that with pyrogallol or gallic acid (tannic acid was excluded because of its molecular complexity). The maximal level of $\mathrm{CBF}$ was observed in acidic $\mathrm{pH}$ range, namely; at $\mathrm{pH}$ values lower than about 7.5-8.0 where phenols would be un-ionized. Above this $\mathrm{pH}$ range the free (unbound) catechin fraction increased rapidly (Figure 2). It confirms that the suppression of the phenolics ionization (i.e., hydrogen bonds between PVPP and catechin become stronger) increase the PVPP binding. ${ }^{5,11,14,15,25}$

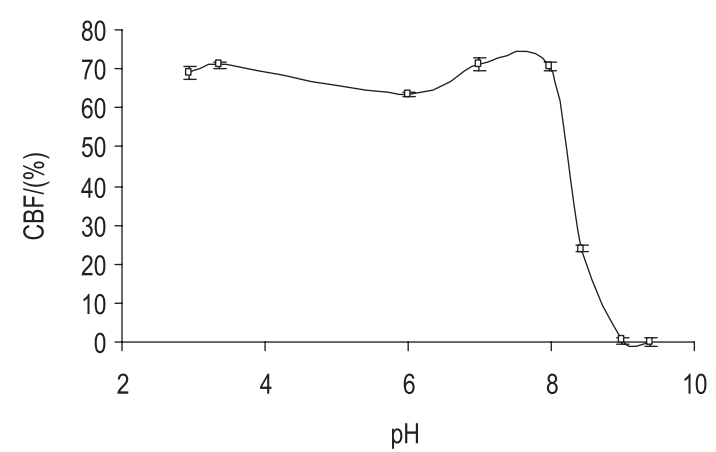

Figure 2. Effect of $\mathrm{pH}$ on the catechin bound fraction (CFB) to PVPP determined by UV detection at $280 \mathrm{~nm}$.

In a former work we asked whether casein and hidepowder were able to bind $P$. guajava tannins in the presence of flavonoids in a specific way. ${ }^{8}$ This question can be extended to PVPP because some of the main features of the casein-tannin and hide-powder-tannin binding are also noticeable in PVPP cases. Alike these protein substrates, the influence of hydrogen bonds and hydrophobic interactions are also manifested in the PVPP molecule, namely, in the pyrrolidone moiety and in the vinyl chain, respectively. ${ }^{28-30}$ It is also worth mentioning that pyrrolidone structure closely resembles some of the proline ones. ${ }^{13}$ So we can compare them and consider that factors such $\mathrm{pH}$, ionic strength and temperature influence the protein binding effectiveness to polyphenol ${ }^{5,28-31,34}$ In our experiments the $\mathrm{pH}$ was acidic (6.0-5.5) and the temperature was always $25 \pm 2{ }^{\circ} \mathrm{C}$.

In this context we studied by UV-Vis and HPLC-PDA techniques the specificity of PVPP to bind catechin and pyrogallol after the addition of rutin.
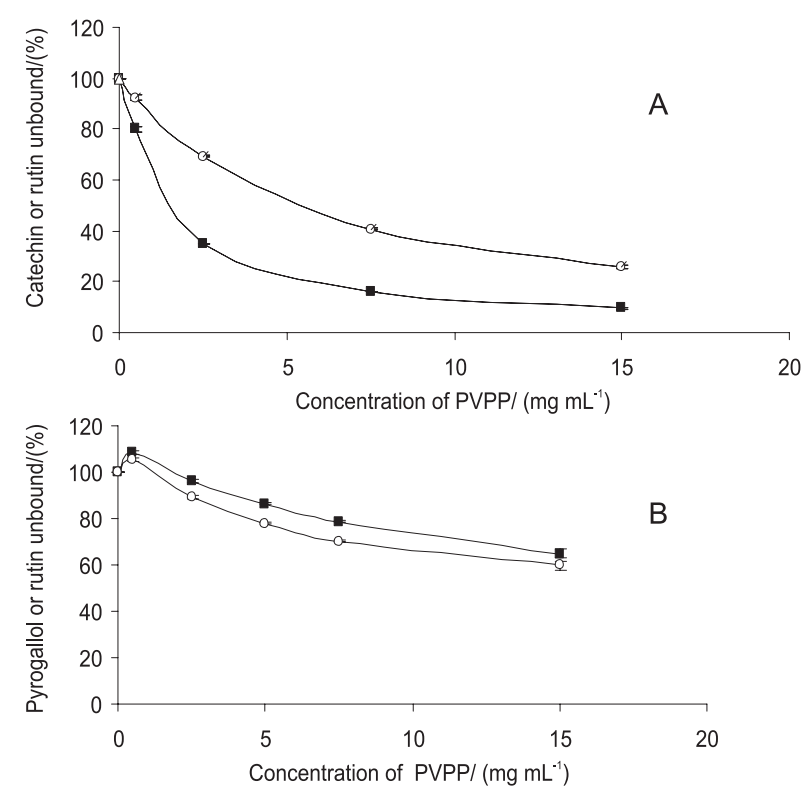

Figure 3. (A) Complexation of catechin and rutin with PVPP; (घ) $280 \mathrm{~nm}$, (O) $352 \mathrm{~nm}$. (B) Complexation of pyrogallol and rutin with PVPP; (匹) $267 \mathrm{~nm}$, (O) $352 \mathrm{~nm}$. Degrees of complexation were determined by UV method.

Comparison of the unbound fractions of rutin and catechin (Figure 3) shows that PVPP is able to bind both substances, but to a different extent.

From the difference between the absorption measured at 280 and $352 \mathrm{~nm}$ it can be seen which compound was bound to PVPP more efficiently. This reasoning is based on the postulation that rutin and catechin absorb strongly at $280 \mathrm{~nm}$, however, at $352 \mathrm{~nm}$ rutin absorbs still strongly while catechin is practically transparent. As the absorption decreases at $280 \mathrm{~nm}$ (due to the mixture of the two substances), it was more marked than that at $352 \mathrm{~nm}$ (Figure 3); it can be inferred that PVPP bound to catechin more readily than to rutin. Both substances have the same number of non-substituted hydroxyl, so the absorption difference is probably due to the steric hindrance caused by the rutoside attached at the rutin $\mathrm{C}-3$ position. ${ }^{23}$ Following a similar train of logic, one can state that PVPP bound to pyrogallol and to rutin in a similar extent.

These results were compared with that obtained by HPLC. A typical HPLC separation of gallic acid, catechin, pyrogallol and rutin is illustrated in Figure 4. Owing its complexity tannic acid was excluded once again from this analysis.

The results are in agreement to the UV-analyses. Significant amounts of all the PRS and rutin were bound to PVPP even with as little as $10.0 \mathrm{mg}$ of PVPP used (Table 1).

The inclusion of a $P$. guajava extract and its analysis by HPLC-PDA represent an approach to evaluate the interference of flavonoids with the binding of other 


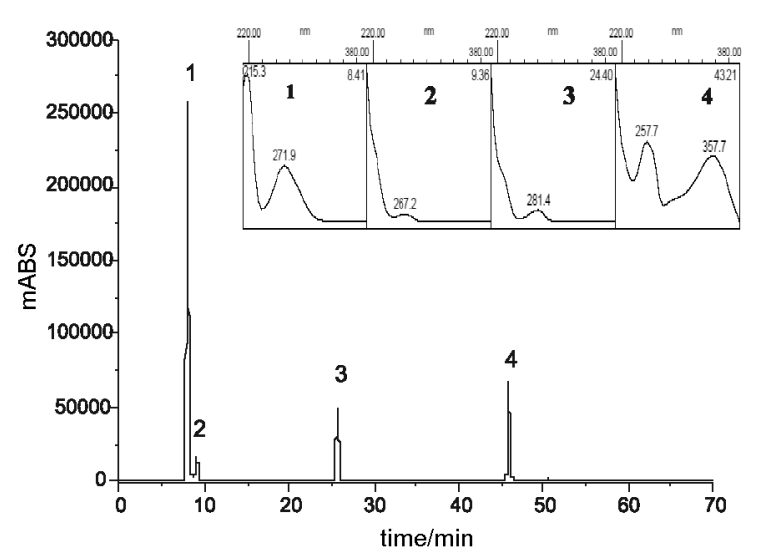

Figure 4. HPLC-PDA-chromatogram of the polyphenolic reference substances: gallic acid (1), pyrogallol (2), catechin (3), and rutin (4) with detection at $280 \mathrm{~nm}$. The insert shows the respective UV spectra.

Table 1. Percentages of bound fraction, determined by HPLC method, for gallic acid, pyrogallol, catechin and rutin after complexation with different amounts of PVPP

\begin{tabular}{lccc}
\hline $\begin{array}{l}\text { Amount of PVPP } \\
\text { added/(mg) }\end{array}$ & $\begin{array}{c}c \\
\text { gallic acid }+ \\
\text { pyrogallol }\end{array}$ & catechin & rutin \\
\hline 10 & $20.13(0.04)^{\mathrm{a}}$ & $73.98(0.27)^{\mathrm{a}}$ & $15.78(0.04)^{\mathrm{a}}$ \\
50 & $56.19(0.27)^{\mathrm{a}}$ & $96.56(0.25)^{\mathrm{a}}$ & $49.70(0.41)^{\mathrm{a}}$ \\
150 & $57.67(0.01)^{\mathrm{a}}$ & $98.95(6.40)^{\mathrm{a}}$ & $75.18(0.32)^{\mathrm{a}}$ \\
300 & $51.76(0.30)^{\mathrm{a}}$ & $99.71(7.59)^{\mathrm{a}}$ & $86.43(0.68)^{\mathrm{a}}$ \\
\hline
\end{tabular}

${ }^{\mathrm{a} C o e f i c i e n t ~ v a r i a t i o n . ~}$

polyphenolics in more complex matrix. The HPLC-PDA analysis of the P. guajava extract along with the co-elution of PRS revealed the presence gallic acid and catechin in this extract (compare Figures 5 and 6 with 4). The occurrence of both polyphenolics was earlier related for this species, together with epicatechin, elagic acid and tannin. ${ }^{17,19,26,27,30}$ Conversely, no peak of the extract HPLCPDA chromatogram could be assigned to rutin.

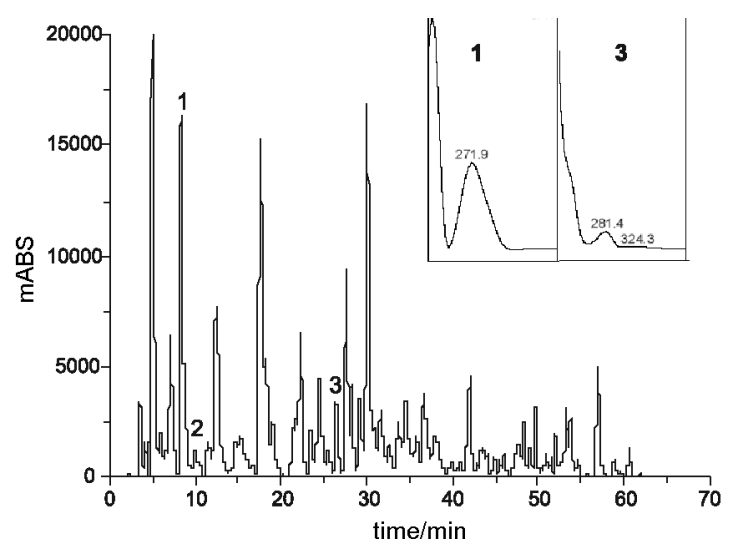

Figure 5. HPLC-PDA-chromatogram of the P. guajava extract showing the presence of gallic acid (1) and catechin (3) after detection at $280 \mathrm{~nm}$. The insert shows the respective UV spectra.
The flavonoid occurrence in P. guajava leaves was extensively related. ${ }^{16-21,27}$ This flavonoid fraction became evident in the HPLC chromatogram after a 45 min retention time and by the detection at a wavelength of $352 \mathrm{~nm}$, at which neither catechin, gallic acid nor pyrogallol exhibits absorption (Figure 6).

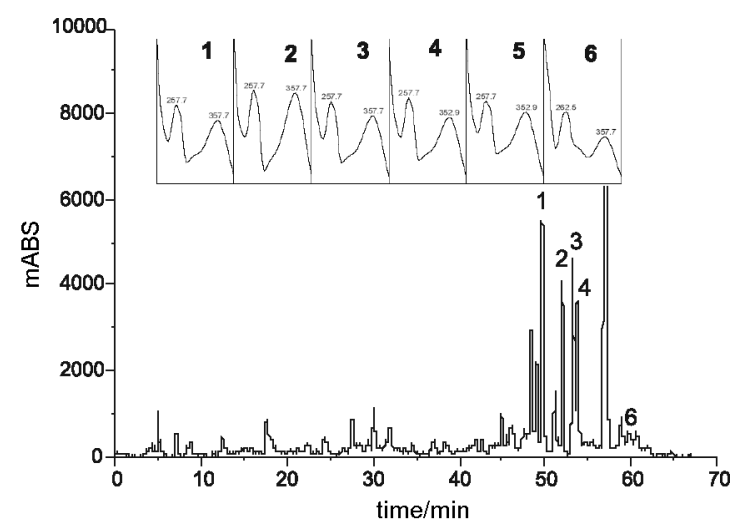

Figure 6. HPLC-PDA-chromatogram of P. guajava extract at a wavelength detection of $352 \mathrm{~nm}$. The peaks coded as $\mathbf{1}, \mathbf{2}, \mathbf{3}, \mathbf{4}, \mathbf{5}, \mathbf{6}$ were characterized as flavonoids. The insert shows the respective UV spectra.

The peaks coded as $\mathbf{1}$ to $\mathbf{6}$ showed UV-spectra that are characteristic of flavonoids, more specifically, flavones. ${ }^{35}$ Five of the HPLC peaks had absorption maxima near 257 and $357 \mathrm{~nm}$, with a shoulder located at about $300 \mathrm{~nm}$ (this resembles that of peak 4 in Figure 4). Those UV-spectra resemble closely the spectra related for some flavonoids isolated from $P$. guajava leaves, among them quercetin and its glycosyl derivatives 3- $L$-4-arabinefuranosid- (avicularine), 3-L-4-piranosid- and 3-O- $\beta$-glycosylquercetin. ${ }^{16-21,27}$ The peak number 6 differs from the other because of their absorbance maxima at 262.5 and $357.7 \mathrm{~nm}$, with a shoulder positioned at about $295 \mathrm{~nm}$, notwithstanding, its flavonoid character can be easily ascribed. ${ }^{35}$

The influence of the increasing treatment with PVPP on the $P$. guajava flavonoid HPLC-fingerprint is summarized in Table 2. As one can observe, the addition of $50.0 \mathrm{mg}$ de PVPP was already capable to bind catechin completely and most of the flavonoid fraction. Moreover, after the addition of 150.0 and $300.0 \mathrm{mg}$ of PVPP all flavonoids and polyphenolics were bound to PVPP in a large extent, with a noteworthy exception of gallic acid.

The results as a whole showed that PVPP was able to bind the test polyphenolics as catechin, tannic acid, pyrogallol and, in a minor extent, gallic acid. However, there was evidence of a lack of specificity when some of the compounds were mixed with rutin. The HPLC-PDA analysis carried out using a $P$. guajava extract led to similar conclusions. Therefore, the results make us discard any possibility of method validation, intended specifically for P. guajava leaves. 
Table 2. Percentages of bound fraction of gallic acid, catechin, and flavonoids of P. guajava after complexation with different amounts of PVPP

\begin{tabular}{|c|c|c|c|c|c|c|c|c|}
\hline \multirow{2}{*}{$\begin{array}{l}\text { Amount of } \\
\text { PVPP } \\
\text { added/mg }\end{array}$} & \multicolumn{2}{|c|}{ Polyphenolic detection at $280 \mathrm{~nm}$} & \multicolumn{6}{|c|}{ Flavonoid detection at $352 \mathrm{~nm}$} \\
\hline & gallic acid & catechin & peak 1 & peak 2 & peak 3 & peak 4 & peak 5 & peak 6 \\
\hline 10.0 & $28.64(2.26)^{\mathrm{a}}$ & $76.53(1.94)^{\mathrm{a}}$ & $36.24(3.16)^{\mathrm{a}}$ & $71.68\left(1.43^{\mathrm{a}}\right)$ & $79.40(1.00)^{\mathrm{a}}$ & $65.00(0.25)^{\mathrm{a}}$ & $55.19(0.14)^{\mathrm{a}}$ & $84.00(1.17)^{\mathrm{a}}$ \\
\hline 20.0 & $30.89(0.25)^{\mathrm{a}}$ & 100 & $37.80(2.84)^{\mathrm{a}}$ & $84.30(1.19)^{\mathrm{a}}$ & $90.67(1.36)^{\mathrm{a}}$ & $77.62(1.41)^{\mathrm{a}}$ & $69.73(0.36)^{\mathrm{a}}$ & $85.35(6.64)^{\mathrm{a}}$ \\
\hline 30.0 & $42.69(4.76)^{\mathrm{a}}$ & 100 & $46.79(1.53)^{\mathrm{a}}$ & $91.21(3.82)^{\mathrm{a}}$ & $94.94(2.04)^{\mathrm{a}}$ & $86.03(0.67)^{\mathrm{a}}$ & $82.41(2.84)^{\mathrm{a}}$ & $86.34(4.96)^{\mathrm{a}}$ \\
\hline 40.0 & $47.38(4.40)^{\mathrm{a}}$ & 100 & $53.90(1.33)^{\mathrm{a}}$ & $93.83(1.72)^{\mathrm{a}}$ & $96.47(3.49)^{\mathrm{a}}$ & $89.78(2.54)^{\mathrm{a}}$ & $87.68(0.99)^{\mathrm{a}}$ & $89.13(8.83)^{\mathrm{a}}$ \\
\hline 50.0 & $57.59(1.62)^{\mathrm{a}}$ & 100 & $68.09(0.64)^{\mathrm{a}}$ & $95.96(3.18)^{\mathrm{a}}$ & $97.72(5.09)^{\mathrm{a}}$ & $92.97(2.20)^{\mathrm{a}}$ & $92.87(1.57)^{\mathrm{a}}$ & $91.35(4.34)^{\mathrm{a}}$ \\
\hline 150.0 & $63.34(0.97)^{\mathrm{a}}$ & 100 & $88.76(2.56)^{\mathrm{a}}$ & 100 & 100 & $97.81(5.20)^{\mathrm{a}}$ & $98.24(1.76)^{\mathrm{a}}$ & $91.95(4.01)^{\mathrm{a}}$ \\
\hline 300.0 & $69.79(0.32)^{\mathrm{a}}$ & 100 & $95.38(8.81)^{\mathrm{a}}$ & 100 & 100 & 100 & $99.44(21.98)^{\mathrm{a}}$ & $91.77(9.94)^{\mathrm{a}}$ \\
\hline
\end{tabular}

${ }^{\mathrm{a}} \mathrm{CV} \%$ : coefficient of variation.

Studies on flavonoid-PVPP structure-affinity relationships had evidenced the influence of other relevant factors, as hydroxyl number, methyl- and glycosylsubstitution patterns and coplanarity of the flavonoid ring C. Thus, highly substituted flavonoids and several isoflavones show little of none interaction with PVPP. ${ }^{22}$ Therefore, the ability of PVPP to bind rutin must be regarded specifically avoiding any oversimplification. The use of PVPP as binding agent aiming the assay of polyphenolics content in vegetable matrixes should be evaluated case by case and further studies are needed.

\section{References}

1. Farmacopéia Brasileira. Atheneu: São Paulo, 1988.

2. Deutsches Arzneibuch. Deutscher Apotheker: Stuttgart, 1998.

3. British Pharmacopoeia. The Stationary Office: London, 1999, v. I.

4. European Pharmacopoeia. EDQM: France, 2002, p. 187.

5. Soares, L. A. L.; Maia, A.; Oliveira, A. L.; Petrovick, P. R.; Ortega, G. G.; Acta Farm. Bonaerense. 2006, 25, 10.

6. Association of Official Analytical Chemists; Official Methods of Analysis of the Association of Official Agricultural Chemists; $12^{\text {th }}$ ed.; Ed. AOAC: Washington, 1975.

7. FAO/IAEA. Division of Nuclear Techniques in Food and Agriculture; Quantification of Tannins in Tree Foliage; Vienna, 2000.

8. Verza, S. G.; Kreinecker, M. T.; Reis, V. Henriques, A. T.; Ortega, G. G.; Quim. Nova. 2007, 4, 815.

9. Schofield, P.; Mbugua, D. M.; Pell, A. N.; Anim. Feed Sci. Tech. 2001, 91, 21.

10. Müeller-Harvey, I.; Anim. Feed Sci. Tech. 2001, 91, 3.

11. Horn, D.; Ditter, W.; J. Pharm. Sci. 1982, 71, 1021.

12. Makkar, H. P. S.; Blummel, M.; Becker, K.; Br. J. Nutr. 1995, 73, 897.

13. Siebert, K. J.; J. Agric. Food Chem. 1999, 47, 353.

14. Andersen, R. P., Sowers, J. A.; Phytochemistry 1968, 7, 293.
15. Plaizier-Vercammen, J. A.; Néve De, R. E.; J. Pharm. Sci. 1982, $71,552$.

16. Jaiarj, P.; Khoohaswan, P.; Wongkrajang, Y.; Peungvicha, P.; Suriywong, P.; Saraya, M. L. S.; Ruangsomboon, O.; J. Ethnopharmacol. 1999, 67, 203.

17. Kondo, S.; Kittikorn, M.; Kanlayanarat, S.; Postharvest Biol. Tec. 2005, 36, 309.

18. Lapcik, O.; Klejdus, B.; Kokoska, L.; Davidova, M.; Afandi, K.; Kuban, V.; Hampl, R.; Biochem. Syst. Ecol. 2005, 33, 983.

19. Lans, C.; Harper, T.; Georges, K.; Bridgewater, E.; Prev. Vet. Med. 2000, 45, 201.

20. Lozoya, X.; Morales-Reyes O, H.; Chavez-Soto, M. A.; Martinez-García, M. D. C.; Soto-González, Y.; Doubova, S. V.; J. Ethnopharmacol. 2002, 83, 19.

21. Oh, W. K.; Lee, C. H.; Lee, M. S.; Bae, E. Y.; Sohn, CL. B.; Oh, H.; Kim, B. Y.; Ahn, J. S.; J. Ethnopharmacol. 2005, 96, 411.

22. Doner, L.W., Bécard, G. Irwin, P. L.; J. Agric. Food Chem. 1993, $41,753$.

23. Frömming, K. H.; Ditter, W.; Horn, D.; J. Pharm. Sci. 1981, 70,738 .

24. Siebert, K. J.; Troukhanova, N. V.; Lynn, P. Y.; J. Agric. Food Chem. 1996, 44, 80.

25. Fickel, J.; Pitra, C.; Joest, B. A.; Hofmann, R. R.; Comp. Biochem. Physiol. 1999, 122, 225.

26. WHO - World Health Organization; Medicinal Plants in the South Pacific, Manila: WHO - Regional Publications Series No. 19, 1998.

27. Gonçalves, J. L. S.; Lopes, R. C.; Oliveira, D. B.; Costa, S. S.; Miranda, M. M. F. S.; Romanos, M. T. V.; Santos, N. S. O.; Wigg, M. D.; J. Ethnopharmacol. 2005, 99, 403.

28. Luck, G.; Liao, H.; Murray, N. J.; Grimmer, H. R.; Warminski, E. E.; Williamson, M. P.; Lilley, T. H.; Haslam, E.; Phytochemistry 1994, 37, 357.

29. Kawamoto H.; Nakatsubo, F.; Phytochemistry, 1997, 46, 479. 30. Santos, S. da. C.; Mello, J. C. P. de In Taninos - Farmacognosia: da Planta ao Medicamento; $3^{\text {rd }}$ ed.; Simões, C. M. O.; Schenkel, E. P.; Gosmann, G.; Mello, J. C. P. de.; Mentz, L. A.; Petrovick, 
P. R., eds., UFRGS: Porto Alegre, UFSC: Florianópolis, 2003, ch. 27.

31. Hagerman, A. E.; Butler, L. G.; J. Biol. Chem. 1981, 256, 4494.

32. Haslam, E.; Lilley, T. H.; Cai, Y.; Martir, R.; Magnolato, D.; Planta Med. 1989, 55, 1.
33. Hagerman, A. E.; Rice, M. E.; Ritchard, N. T.; J. Agric. Food Chem. 1998, 46, 2590.

34. Freitas, V. de. Mateus, N.; J. Agric. Food Chem. 2001, 41, 940.

35. Harborne, J. B.; Mabry, T. J.; Mabry, H.; The Flavonoids, Academic Press: New York, 1975.

Received: October 31, 2007 Web Release Date: October 15, 2008 